\title{
A Comparative Between Influence of Antibiotics and Extracts from Myrtus Communis and Allium Sativum Against S. Aureus Isolated from Some Pathogenic States
}

\author{
Alaa Saeed Sheet ${ }^{1}$, Saad Hameed Abood ${ }^{2}$, Safaa M. Sultan ${ }^{3}$, Sawsan \\ Moayed Alomari ${ }^{4}$ \\ \{alaasaeedsheet@yahoo.com,saadhameed54@yahoo.com,waseemthabit@yahoo.com,saf \\ aahawija@gaiml.com\} \\ Northern Technical University ${ }^{1}$ Al_iraqia University ${ }^{2}$, Northern Technical \\ University $^{3}$, Northern Technical University ${ }^{4}$
}

\begin{abstract}
Aim of the study included isolating staphylococcus aureus bacteria for several different medical conditions and revealing the most important virulence factors it possesses. Determination of the presence of staphylococcus aureus bacteria that are resistant to antibiotics and isolated from this conditions.ccomparative between the effect of antibiotics used in this study on S.aureus with the effect of alcoholic and aqueous extracts of the Myrtus communis and Allium sativum, 125 samples were collected on different clinical cases (wounds, acne, tonsils, ear, eye) The results showed that the highest rate of isolation of Staphylococcus aureus bacteria is from samples taken from wounds, Until it reached its lowest sensitivity to the anti-G Penicillin direction, as it reached 5\%, the alcoholic extract of garlic was the first in its inhibitory effect on S.aureus isolates for all concentrations used understudy, so it showed high moral inhibition and overcome the standard drug (Control) Vancomycin Alcoholic extract of the ace plant followed, as the concentration appeared between $(100,75) \mathrm{mg} / \mathrm{ml}$, The aqueous extract of the base plant came last. The standard drug Vancomycin showed a significant moral superiority over the extract and for all the concentrations used under study.
\end{abstract}

\section{Introduction}

Although Staphylococcus aureus is part of the normal flora of the skin, nose, pharynx and gastrointestinal tract and reproductive tract of the human being, they are important nurses for the human being as they cause numerous injuries ranging from difficult to possible treatment due to their ability to penetrate the body's defenses and invade tissues by possessing various ferocity factors as well in multiplicity Opportunistic Pathogens It causes minor skin infections to life-threatening systemic diseases, as it has a high ability to resist antibiotics [1-2], as the most serious infections are caused by multiple strains resistant to antibiotics oxacillin resistant staphylococcus aureus. Which became a serious health problem [3]. These bacteria infect different areas of the body such as the eye, throat, pharynx, urethra, vagina, and stomach, but they become more dangerous when they enter the bloodstream, causing diseases such as pneumonia, urinary tract infection, tonsillitis and nasal sinuses [4-5] Staphylococcus aureus (Staphylococcus aureus) has the ability to produce hemolysin called staphylolysines, as well as staphylokinase, to help spread bacteria, cerebellum formation, leucocidin, and hyaluronidase, as well as its ability to cause endocarditis [6-8]. Medium diseases and toxins such as Toxic shock syndrome and food poisoning [9] are also the most important causes of skin infection such as boils, Pimples, Abscesses, Impetigo, and wound infection. Scalded Skin Syndrome [10] has a role in causing impetigo injuries that multiply into acute inflammation, such as Acne [9-11]. This is why bacteria have an important role in Osteomyelitis [12], so efforts are now being replaced to use a therapeutic side. Another safer antibiotic is a good plant extract that has the inhibiting effect of different types of microorganisms 


\section{Materials and working methods:}

130 samples of samples (wounds, acne, tonsils, ear, eye) were collected from patients attending the General Teaching Hospital in Al-Kirkuk city at the age of (10-60) years for the period (1/12/2018 - 1/4/2019). Cultivation on the agricultural media on the solid salt mannitol medium and the blood agar medium and the solid nutrient medium and then diagnose the staphylococci bacteria by electing the colonies growing on the mannitol medium and fermenting it, and then conducting diagnostic tests for all isolates according to what is mentioned in [13-15].

The ability of bacteria to produce coagulase was determined in two ways:

1. Piping: To extend the free enzyme, as $1 \mathrm{ml}$ of plasma was taken and placed in a sterile tube, and the vaccine and bacterium were added to it by the carrier and incubated at a temperature of $37 \mathrm{C}$ for a period of four hours. If the clotting is an indication that the bacteria produce the clotting enzyme if the plasma remains as it demonstrates the inability of bacteria to produce a plasma coagulation enzyme.

2. Slide: It is conducted to determine the binding enzyme and is done by taking a drop of plasma and putting it on sterile slides, then pollinated by the transferor with the bacterial vaccine and mixed well with it. After ten minutes, a clotting presence and a lack of it is observed as the plasma clotting is a positive result

As for determining the production of the hemolysin enzyme, it was done in the following way:- The dishes containing the blood acids medium were stalked with bacteria of staphylococcus and incubated with a temperature of $37 \mathrm{~mm}$ for 24 hours that the emergence of a transparent decomposition area around the colonies is a positive result and vice versa. 14) Hence, a staphylococcus aureus isolates sensitivity test is performed

For antibiotics according to [16]. As 4-5 pure colonies were transferred to test tubes containing $5 \mathrm{ml}$ each of the broth medium and incubated tubes at a temperature of $37 \mathrm{~mm}$ 24 hours after which the growth in the tubes was compared with the McFarland tube and equal to approximately $1.5 \times 108$ cells $/ \mathrm{ml}$ and using Sterile cotton swab spreading bacteria to test their sensitivity on the Muller Hinton steel medium evenly and ready-made antibiotic tablets were placed on the surface of sterile dishes by sterile forceps and gently pressed and then brooding at a temperature of $37 \mathrm{C}^{5}$ for 24 hours then determine the resistant and sensitive bacteria of life antibodies by measuring the diameter of the inhibition region from the second side of the plate using a transparent ruler, after which it was compared with the records fixed in the standard table [17]. National Committee of Clinical Laboratory standers.

Yace leaf was obtained from the college garden and garlic plant from the local market. Then the Yace leaves and garlic cloves were washed with plain water and then distilled water then left to dry at room temperature then crushed dry leaves of Yace with an electric mill and kept the powder with a dry bottle until use, then the aqueous extract of a plant is prepared yace and garlic, as stated in [18], which include mixing a quantity of

Dry powder of yace plant with a quantity of garlic crushed with an electric mill with a quantity of distilled water in the proportion of $1 \mathrm{~g}: 2 \mathrm{ml}$ distilled water using an electric mixer Blender at room temperature Leave the solution for 24 hours and then filter the resulting mixture by several layers of sterile medical gauze then distribute the suspended substance from the filtration In test tubes in the centrifuge at $3500 \mathrm{rpm}$

The filtrate was taken for the purpose of drying with an electric oven with a temperature of $\left(35^{\circ} \mathrm{C}\right)$ equipped with an air fan to prepare a hot air stream in drying on the one hand and to reduce the effect of heat on the components of the extract on the other hand in order to prevent any changes that might lead to a decrease in the biological effectiveness of the extracts after the weight of the dry powder and keep clean glass bottles tightly closed and placed in the refrigerator until use. As for the method of preparing alcoholic extracts for pomegranate peel plant, it was done according to [19].

As $15 \mathrm{~g}$ of garlic or yace powder were taken and $200 \mathrm{ml}$ of ethyl alcohol was added to it at a concentration of $80 \%$ and put in Thumblc in a continuous extract device and the extract was left for 7 hours at a temperature of $60 \mathrm{C}^{5}$ then filtered with a filter type 1 . Watt man No The filtrate was then exposed to evaporation using the Rotary vacuum evaporator until a thick liquid was obtained, after which the liquid was evaporated using the $45^{\circ} \mathrm{C}$ 
electric oven to obtain the dry powder. Stock Solution prepared by taking $2 \mathrm{gm}$ aqueous extract was dissolved and dissolved in (10) $\mathrm{ml}$ of sterile distilled water, so its concentration became $200 \mathrm{mg} / \mathrm{ml}$, and ascending concentrations were prepared $(25,50,75,100) \mathrm{mg} / \mathrm{ml}$. As for the control treatment, it was represented by distilled water only.

As for alcoholic extracts, the standard dilutions were prepared using ethylene glycol at a concentration of $100 \%$ as a diluent and a good solvent and ineffective against microorganisms if they were used as a control treatment as well and the diffusion method in agar was used by drilling [12].

This method included making five holes with a diameter of $6 \mathrm{~mm}$ by a cork purer in equal dimensions, then spreading $0.1 \mathrm{ml}$ of the bacterial trap by the publisher (Spreader) homogeneously over the Muller Hinton medium (after comparison with the standard McFarland tube), then the prepared concentrations were added to each extract $(25,50,100$, 200) $\mathrm{mg} / \mathrm{ml}$ by $0.1 \mathrm{ml}$ per hole with control remained. Then the dishes were incubated at $37^{\circ} \mathrm{C}$ for 24 hours after which it was possible to know the efficacy of the extract by measuring the inhibition zone by ruler around each hole.

\section{Results and Discussion}

The highest incidence of Staphylococcus aureus isolation was recorded in samples taken from wounds $76 \%$, followed by acne $56 \%$, then ear $36 \%$, tonsils $28 \%$, and finally the eye $20 \%$. It was found from the results of the study that most of the bacteria producing the coagulation enzyme are producing hemolysin which is the most important Firm factor of this bacterium are described. It is observed that there is a close correlation between the susceptibility of bacteria to hemolysin production and plasma coagulation.

Table. 1. Types of Staphylococcus aureus isolated from clinical samples understudy

\begin{tabular}{|l|c|c|c|c|c|c|}
\hline Isolation of S.aureus & \multicolumn{2}{|l|}{ Total of isolation } & \multicolumn{2}{l|}{$\begin{array}{l}\text { NO. isolation product } \\
\text { hemolysin }\end{array}$} & \multicolumn{2}{l|}{$\begin{array}{l}\text { NO. isolation, not } \\
\text { product hemolysin }\end{array}$} \\
\hline & NO & $\%$ & NO & $\%$ & NO & $\%$ \\
\hline & 32 & 59.2 & 29 & 91 & 3 & 9 \\
\hline & 22 & 41 & 6 & 27 & 16 & 73 \\
\hline
\end{tabular}

Table. 2. Percentage of S.aureus isolates produced and coagulase.

\begin{tabular}{|c|c|c|c|c|c|c|c|}
\hline $\begin{array}{c}\text { Samples } \\
\text { Clinical }\end{array}$ & $\begin{array}{c}\text { Number } \\
\text { Samples }\end{array}$ & \multicolumn{2}{|c|}{ S.aureus } & \multicolumn{2}{c|}{ Staphylococcus spp. } & \multicolumn{2}{c|}{ No growth } \\
\hline & & NO & $\%$ & NO & $\%$ & NO & $\%$ \\
\hline Wounds & 25 & 19 & 76 & 4 & 16 & 2 & 8 \\
\hline Acne & 25 & 14 & 56 & 8 & 32 & 3 & 12 \\
\hline Tonsils & 25 & 7 & 28 & 14 & 56 & 4 & 16 \\
\hline The ear & 25 & 9 & 36 & 10 & 40 & 6 & 24 \\
\hline Eye & 25 & 5 & 20 & 15 & 60 & 5 & 20 \\
\hline Total & 125 & 54 & & 51 & & 20 & \\
\hline
\end{tabular}

The sensitivity of S. aureus isolates has been studied in the direction of several selected life antibiotics, as Table (3) shows that there is a clear variation in the resistance of Staphylococcus aureus isolates to these antagonists. It showed high resistance to Penicillin $\mathrm{G}$, as it reached $100 \%$. As the use of these antihistamines became limited due to their possession of a B-lactam ring in addition to the ability of these bacteria to resist these antihistamines to produce beta-lactamase enzymes encoded by plasmids or chromosomes [22] and there was high resistance to the anti-Amoxicillin and Ciprofloxacin by $96 \%$ for each of them then graded Resistance became close to Chloramphenicol, Nitrofuration, and Tetracycline, Rivampicin $(56,48,44,41 \%)$, respectively, then resistance to Neomycin decreased to $37 \%$, reaching Vancomycin as it reached $0 \%$. Resistance to Tetracycline was encoded in Staphylococcus aureus by [15] whereas, the resistance of Rifampicin antigen 
then changed the target site of this antagonist, which is the DNA-Depended RNAPolymerase with chromosomal mutations [23,24]. The Vancomycin antagonist is considered to be a killer antagonist, inhibiting the synthesis of the cellular neighbor by preventing the binding of the molecules of the peptidoglycan polymers [25].

Table. 3. percentages of isolates resistant to antibiotics for Staphylococcus aureus.

\begin{tabular}{|c|c|c|c|c|c|}
\hline \multirow[t]{2}{*}{ Antibiotic } & \multirow{2}{*}{$\begin{array}{c}\text { The } \\
\text { concentratio } \\
n \text { of } \\
\text { antibiotic in } \\
\text { disc } \\
\end{array}$} & \multicolumn{2}{|c|}{ Resistance isolation } & \multicolumn{2}{|c|}{ Sensitive isolation } \\
\hline & & NO & $\%$ & $\mathrm{NO}$ & $\%$ \\
\hline Neomycin & $10 \mathrm{gm}$ & 20 & 37 & 34 & 63 \\
\hline Penicilling & $10 \mathrm{gm}$ & 54 & 100 & 0 & 1 \\
\hline Amoxicillin & $10 \mathrm{gm}$ & 52 & 96 & 2 & 4 \\
\hline Tetracyclin & $30 \mathrm{gm}$ & 24 & 44 & 30 & 56 \\
\hline Chloramphenicol & $30 \mathrm{gm}$ & 22 & 41 & 32 & 59 \\
\hline Vancomycin & $5 \mathrm{gm}$ & 0 & I & 54 & 100 \\
\hline Cloxacillin & $5 \mathrm{gm}$ & 47 & 87 & 7 & 31 \\
\hline Ciprofloxacn & $30 \mathrm{gm}$ & 52 & 96 & 2 & 4 \\
\hline Nitrofurantion & $300 \mathrm{gm}$ & 30 & 56 & 4 & 44 \\
\hline Rifampicin & $5 \mathrm{gm}$ & 26 & 48 & 28 & 52 \\
\hline
\end{tabular}

Table (4) shows that the alcoholic extract of the garlic plant came first in its effect on staphylococcus aureus. The standard drug Vancomycin did not show any significant superiority over the extract and all the concentrations used understudy, but the extract showed all its concentrations the effect of high moral inhibition and overpowered the drug (Control) came second in the alcoholic extract of the acetate plant, As the standard drug Vancomycin showed significant superiority over the extract with a concentration of (22.50) $\mathrm{mg} / \mathrm{ml}$, as the damping diameter of the standard drug was $16.9 \mathrm{~mm}$, while the two concentrations $(75,100) \mathrm{mg} / \mathrm{ml}$ showed a superior inhibitory effect. The aqueous extract of garlic ranked third, as the standard drug outperformed the extract by concentrations (25, $50,75) \mathrm{mg} / \mathrm{ml}$, while the concentration showed $100 \mathrm{mg} / \mathrm{ml}$, a superior inhibitory effect. The water extract of the exponent plant came in the last place, as the standard showed significant superiority over the extract and all its concentrations. We conclude from all the above that the alcoholic extract has overcome the aqueous extract of the medicinal plants used understudy to inhibit the isolates of staphylococcus aureus.

Perhaps this is due to several reasons, including the method used in the extraction, as well as the type of bacteria located under the extract stream and the nature of the substances present in the aqueous extract are somewhat different from that in the pseudo-extract liberating an enzyme as we note that the bacterial inhibition process is proportional to the increase in the concentration of the extract as it was mentioned [18] that the more concentrations of the inhibitory substance in the extract, the greater its concentrations, the greater its effective effect on inhibition of the bacterial species. We also deduced from this study the increased inhibitory efficacy of garlic on the wall to inhibit staphylococcus aureus isolates as garlic contains volatile oils consisting of volatile compounds consisting of sulfur compounds such as Diallyl trisulfide, Diallyl disulfide, Allicin, as Allicin oil is responsible for the therapeutic properties of garlic, as the Allinase enzyme is released and the Allin compound turns into the active allicin compound that has the Allicin compound found in garlic. It has a wide inhibiting activity against viruses, bacteria, and fungi, especially against staphylococcus aureus causing secondary infections such as deadly pneumonia especially in young children.

Table. 4. Inhibitory effect of aqueous and alcoholic extracts of medicinal plants understudy on Staphylococcus aureus isolates

\begin{tabular}{|c|c|c|c|c|c|c|c|}
\hline $\begin{array}{c}\text { Plant } \\
\text { used }\end{array}$ & $\begin{array}{c}\text { Commend } \\
\text { name }\end{array}$ & $\begin{array}{c}\text { Family } \\
\text { name }\end{array}$ & Antibiotic & $\begin{array}{c}\text { Type of } \\
\text { extract }\end{array}$ & \multicolumn{3}{|c|}{$\begin{array}{c}\text { Size of Inhibition zone } \\
\text { For 5concetrationecxtract }\end{array}$} \\
\cline { 5 - 9 } & & & 25 & 50 & 75 & 100 \\
\hline
\end{tabular}




\begin{tabular}{|c|c|c|c|c|c|c|c|c|}
\hline $\begin{array}{l}\text { Allium } \\
\text { sativum }\end{array}$ & $\begin{array}{c}\text { Garlic } \\
\text { (lopes) }\end{array}$ & Liliaceae & $\begin{array}{c}\text { Inhibition } \\
\text { zone } \\
\text { Vancomycin } \\
19.6 \mathrm{~mm} \mathrm{~cd} \\
\end{array}$ & aqueous & $17 \mathrm{a}$ & $17.4 \mathrm{~b}$ & $19.1 \mathrm{c}$ & $22 \mathrm{~d}$ \\
\hline & & & $\begin{array}{c}\text { Inhibition } \\
\text { zone } \\
\text { Vancomycin } \\
19.6 \mathrm{~mm} \mathrm{a} \\
\end{array}$ & $\begin{array}{l}\text { alcoholi } \\
\text { c }\end{array}$ & $21 \mathrm{ab}$ & $25 \mathrm{c}$ & $28.3 \mathrm{~d}$ & $33.4 \mathrm{e}$ \\
\hline \multirow[t]{3}{*}{$\begin{array}{l}\text { Myrtus } \\
\text { commun } \\
\text { is }\end{array}$} & \multirow[t]{3}{*}{$\begin{array}{l}\text { Myrtle } \\
\text { leaves }\end{array}$} & \multirow[t]{3}{*}{ Myrtaceae } & $\begin{array}{c}\text { Inhibition } \\
\text { zone } \\
\text { Vancomycin } \\
19.6 \mathrm{~mm} \\
\end{array}$ & $\begin{array}{l}\text { Aqueou } \\
\mathrm{s}\end{array}$ & $\begin{array}{c}19.3 \mathrm{~d} \\
\mathrm{e}\end{array}$ & $18.3 \mathrm{c}$ & $16.3 \mathrm{~b}$ & $15.6 \mathrm{a}$ \\
\hline & & & $\begin{array}{c}\text { Inhibition } \\
\text { zone } \\
\text { Vancomycin } \\
19.6 \mathrm{~mm} \mathrm{bC} \\
\end{array}$ & $\begin{array}{l}\text { alcoholi } \\
\text { c }\end{array}$ & $22.7 \mathrm{e}$ & 20.cd & $19.3 \mathrm{~b}$ & $15.6 \mathrm{a}$ \\
\hline & & & & $\begin{array}{l}\text { Athelin } \\
\text { glycol }\end{array}$ & 0 & 0 & 0 & 0 \\
\hline
\end{tabular}

And pomegranate evil contains other important compounds Allin (S-ally-L-Cysteine sulfoxide (S-methyl-L-Cysteine, sulfoxide) and proteins, vitamins, and enzymes such as (Allinase, Peroxidase, Myrosinase) [26] Also, the sulfur bonds of the compound Allicin increase the effectiveness Antibiotics for this plant [27]. Also, the extract of the leaves and fruits of ace has a deadly and inhibitory effect of Staphylococcus aureus isolates, which contains volatile essential oils, resins, sugars and glycerides, and the oils contain many substances including Alpha Pinene, Camphene, Nerol, Geraniol, cineole, Myrtol, Dipinene [23]. Also, the good inhibitory activity of acetylcholine, which is positive for gram stain, even at low concentrations, is due to the presence of flavonoid glycosides which, when hydrolyzed, give the compounds Ellagic acid, Gallic acid, Myricetin is effective against bacteria that are positive for the dye of a particular gram Staphylococcus aureus [19]. It was also mentioned that two new compounds of Yace leaves, A-Myrtucommulone, and BMyrtucommulone, were observed, as the effectiveness of the Myrtucommulone-A compound was observed against gram-positive bacteria [27].

Different letters within a single row mean that there is a significant difference at the level of $(\mathrm{P}<0.05)$.

Similar letters within a single row mean that there is no significant difference at the level of $\mathrm{P}<0.05)$ )

LSD values for aqueous garlic extract 0.9

LSD values for Alcoholic Garlic Extract 1.67

LSD values for the aqueous extract were 1.055

LSD values for the alcoholic extract were 1.16

\section{Conclusion}

This paper studied the isolating staphylococcus aureus bacteria for several different medical conditions and revealing the most important virulence factors it possesses. Determination of the presence of staphylococcus aureus bacteria that are resistant to antibiotics and isolated from this conditions.ccomparative between the effect of antibiotics used in this study on S.aureus with the effect of alcoholic and aqueous extracts of the Myrtus communis and Allium sativum.

\section{References}

[1] Todyar, KStaphylococcus.J.Med. Microbial, p.1-9 (2012). 
[2] Klevens, E.: Invasive methicillin.resistant Staphylococcus aureus in Fections in the united states. JAMA. Retrieved on 2007-10-31 (2017)

[3] Murry, B.E.: Staphylococcus infections. Text book of pediatric infection disease, 3th-ed. Bol 2., Saunders philabdelphia 2014)

[4] Collee, J. G., Fraser, A. G., Marmion, B. P. and Simmons, A.: Mackine and Mccarteny (PRACTICAL MEDICAL MICrobiology) $14^{\text {th }}$ ed . Churchill Living stone, neu york (2015)

[5] Blot, S., Vandwoyde , K., Hoste , E. and Colardyn, F.: Out cone and attributable mortality in critically 111 patents with bacteremia anvolving methicillin-sus ceptible and methicillin res istant Staphylococcus aureus . arch antern . med 162 (19) p: 2229-2235 (2012)

[6] Rybak, M. J., Lerners, S. A., Levine, D. P., Albrech, L. M., Mcneil, P.L., Hampson,G.A., Kenny, M.T., and Yuh, L.: Teicoplanin pharmacokin etics in intervneous druh abusers being treated for bacterial endo carditis. Antimicrob. Agents chemother ,35(4),P:696-700 (2018)

[7] Roder, B. L., Wandall, D. A., Moller, N. F., Espersen, F., Skinnoj, P. and Rosdahi, V.T.: Clinical featuers of staphy looccus aureus endocarditis.Arch.Intern.med.159, P; 462-469 (2016)

[8] koneman, E. W., Allen, S. D., Janda, W. M., Schreck ebergev, P.C., and win,W.C.: Color atlas and textbook of diagnostic microbiology.5th.ed J.B.Lippincot Raven Publisher Philadelphia, (2015) [9] Cruickshank, R., Dughid, J. P., Marmion, B. P., and Swain, R. A.: Medical microbiology 12th.ed Churchill Living stone, London, (2014)

[10] Bowling, F. L., Salgami, E. V., and Boulton, A. J.: Larval therapy; a novel treatment in eliminating methicillin resistant staphylococcus aureus from diabetic foot ulcers.Diabetes care 30(2),P:370, (2017)

[11] Mims, C. A., Playfair, J. H., Roit, J. M., Wakelin, D., Williams, R., and Anderson, R. M.: Medical microbiology. Mosby, London (1995)

[12] Musa, H. A., Hamdam, T. A., and Baker,S. S.: Clinical and microbiological evaluation of osteomyeliyis Bahrain . med. boull .23 (2), pp. 61-65 (2016)

[13] koos, W. E. and Banernan, T. L.: Staphylococcus and micrococcus. manual of clinical microbiology. 6th -ed. AMERICAN society for microbiology (2015)

[14] Macfadden, J.F.: Biochemical tests for identification of medical becteria .3th-ed. william and wilkins , USA (2015)

[15] Sneath, P. H. A.; Hoh, J. G.; krieg, N. R.; Staley, J. T. and Williams, S. T.: Bacteriology.9th-ed. Williams and Wilkins company (2014)

[16] Bauer, A. W., Kirbay, W. A. M., Sherris, J. S., and Turk, M.: Antibiotic susceptibility testing by a stan dardized single disc Method. Am.J. clin. pathol, Vol. 45, pp. 493-496 (2015)

[17] National Committee for Clinical Laboratory Stan dards (NCCLS). Performance standards for antimicrobial susceptibility testing. Twelfth information supplement, (2012)

[18] Hernandez, M.; Lopez, R.; Abnans, R. M.; Paris, V. and Arias, A.: Antimicrobial activity of visnea mocanera leaf extracts, J.; Ethnopharmacology, 41, P:115-119 (2015)

[19] Deshmurh S. D. and Boral,M. N.: Studies on the insectical properties of indigenous plant products Indian J.Ent.37(1),pp. 11-18 (2016)

[20] Lyon. B. R. and Shurray, R.: Antimicrobial resistance of staphylococcus aureus. Gentic. Microbiol. Rev .51, pp. 88-130 (2018)

[21] Tylor, D. E.: Teracycline resistance Mediated by ribosomal protection. J. Antimicrobial Agents chemother, Vol. 40, pp.1-5 (2014)

[22] Schmitz, F. J., Fluit , A. C., Hofener, D., Beeck. A., Perdilouli ,M., Boos, M., schearing, S., Verhoef, F., Kohrer,K., and von -Eiff, C.: Development of resistance to ciprofloxacin, revampicin and Mupirocin in methicillin-susceptible and resistance staphylococcus aureus isolates.J.Antimicrobial .Agents chemother, Vol. 44, pp. 3229-3231 (2018)

[23] Gonzalezzom, B., and Conrvalin, P.: Glycopeptide resistance staphyiococcus aureus Lancet. Infect. Dis, Vol. 3, pp. 67 (2013)

[24] Raj, K. P., and Pramar, R. M.: Garlic condiment and medical. Ind. Drugs, Vol. 15, pp. 205-208 (2017)

[25] Tsao, S., and Yin, M.: In vitro antimicrobial activity of four diallylsulphides occurring naturally in garlic and Chinese leek Dils. J. Med. Microbial, Vol. 50, pp. 646-649 (2016)

[26] Husein, F. T.: Medical plants in Libya. Isted. Faculity of pharmacy, AL. fateh university, Tripoli,Libya. 2th-ed.W.B. saunders company, USA (2014)

[27] Kashman, K., Rotsein, A., and Lisfshitz, A.: The structure determination of two new acylph. Orogluciols from Myrtus communis. L. Tetranedron, Vol. 30, pp. 991-997 (2017) 